Chang, C. (2016). The Efficacy of a One-to-one Technology Initiative in Improving the Four Cs. Journal of

Educational Technology Development and Exchange, 9(2), 21-38.

\title{
The Efficacy of a One-to-one Technology Initiative in Improving the Four Cs
}

\author{
Ching-Wen Chang \\ Missouri State University
}

\begin{abstract}
The Ozarks Educational Research Initiative, a consortium of 19 Southwest Missouri public school districts, partnered with Missouri State University's Institute for School Improvement from 2011 - 2015 to investigate effective practices for utilizing one-to-one digital technologies in the classroom. The focus of this descriptive study was to determine whether a one-to-one technology initiative would result in improving any of the "four Cs" (communication, collaboration, creativity, or critical thinking) of the Framework for 21st Century Learning. Of the teachers surveyed who have one-to-one classrooms, three-quarters of them (77.5\%) believe there were improvements in the four Cs as a result of the introduction of one-to-one technology (laptops, tablets, or iPads) into their classrooms.
\end{abstract}

Keywords: one-to-one technology, technology initiative, technology immersion, K-12 technology, $21^{\text {st }}$ century learning skills

\section{Introduction}

The Institute for School Improvement (ISI) is the research arm of the College of Education at Missouri State University. In 2011 a collaborative project was developed between the ISI and the Ozarks Educational Research Initiative, "The Ozarks Educational Research Initiative (OERI) is a research, evaluation, and development organization whose primary purpose is to improve, promote, and disseminate educational research by conducting studies and program evaluations" ("Ozarks Educational Research Initiative", 2013, ๆ1).
The ISI-OERI collaboration is a partnership between the Institute for School Improvement and 19 Southwest Missouri public school districts with a combined enrollment of over 75,000 students; including a K-12 Laboratory School located on the Missouri State campus. This collaboration has been active since 2007, initiating successive two-year projects. The first study, from 2007 - 2009, involved research on school climate and leadership. The research project for the next two years involved successful practices with middle school Special Education students to increase their literacy achievement that ran from 2009- 2011. 
In 2011 , the OERI member superintendents identified the integration of technology as a major educational change that would occur in three to five years. This led them to select one-to-one technology as the ISI-OERI research project for 2011-2013.The intent of the two-year study was to investigate the effectiveness of one-to-one technology immersion in the 19 districts. The two-year study evolved into a four-year study which ran through 2015.

Each school in the consortium chose what technology was to be provided to the students: laptops, tablets, or iPads. Because of funding limitations, there were schools that only provided one-to-one technology at an individual grade level. Those schools with severely restricted budgets adopted a "bring your own device" (BYOD) model in order to participate in the study. A set of survey questions was developed by the OERI research team and approved by the OERI member superintendents to administer to the participants for feedback.

\section{Purpose of the Study}

The focus of this descriptive study was to determine, from the perspective of the one-to-one classroom teachers, the efficacy of the one-to-one technology immersion in relation to one specific aspect of the overall technology initiative, namely the "four Cs"(communication, collaboration, creativity, or critical thinking) found in the Framework for $21^{\text {st }}$ Century Learning(2002). Using the Framework for $21^{\text {st }}$ Century Learning as the theoretical framework for this research, the goal of this study was to provide insight into whether or not a one-to-one technology implementation impacted these parameters across abroad cross-section of Missouri school districts. The research question used to help in the collection of relevant data:
- From the teachers' perspective, does the use of one-to-one technology immersion in the classroom impact any of the "four Cs" - communication, collaboration, creativity, or critical thinking?

\section{Significance of the Study}

One-to-one computer initiatives are expanding rapidly across the globe, but knowledge about one-to-one initiatives has not kept up with this expansion (Penuel, 2006). The current climate of technology initiatives in K-12 education in Missouri appears to be following this global trend, making the OERI member superintendents' selection for the 2011-2013 ISI-OERI collaboration a cogent research project. Bebell and O'Dwyer (2010) state that one-to-one computing " refers to the level at which access to technology is available to students and teachers" and further that " having a robust access ratio of one computer to one student would seemingly provide an optimal setting for the study of how educational technology can impact teaching and learning" (p. 5). The OERI study tests this theory in the southwest Missouri school districts. If one-to-one technology initiatives are successful, this would have significant implications for school effectiveness, learning strategies, assessment activities, strategic planning for technology, and technology budget justification.

The proliferation of computers in the classroom is obvious, and school districts nation-wide have spent billions implementing computer-mediated instruction (Weston \& Bain, 2010). The national student-to-computer ratio has dropped from 125:1 in 1983 to 4:1 in 2002 (Bebell \& Kay, 2010) and the ratio is undoubtedly lower still today. The decision of the OERI member superintendents to select one-to-one technology as a research project reflects these trends and provides additional 
data for consideration. In order to provide a scholarly basis for this study, what follows next is a review of the existing literature.

\section{Literature Review}

The literature is replete with studies about the impact of technology on learning. Educators have been studying the effects of mediated instruction for over a century. As early as 1910 the first catalog of instructional films for public schools was published. Several decades later the Ford Foundation funded a nationwide study that included over 200,000 public school students, based on the results of a 1956 experiment on the use of closed-circuit instructional television in Hagerstown, Maryland (Hirumi, 2011). When personal computers became prevalent in the classroom, history repeated itself and computer-based instruction, computer-based training, laptop initiatives and so on, became the new educational technology paradigm to be compared with traditional classroom instruction.

One-to-one computing which was initially referred to as ubiquitous computing- a term coined by Mark Weiser - describes technology that is always present. Similar to utilities such as electricity, Weiser (1991) envisioned ubiquitous computing as technologies that "weaves themselves into the fabric of everyday life until they are indistinguishable from it" (p. 94).

Marc Prensky author of the now famous manuscript Digital Natives, Digital Immigrants (2001a) described significant differences between the generation that grew up with digital technology which he calls digital natives; those who grew up before these technologies existed he refers to as digital immigrants. Virtually all of the students are now digital natives and Prensky suggests the implications for educators are immense, and that educators must find new ways to present content to this generation of students. The current study should help determine if a one-to-one technology initiative such as the one undertaken by the OERI consortium might provide an alternative way to deliver content.

The first (if not the first, certainly the most visible) major project involving one-toone computing was a Microsoft's Anytime, Anywhere Learning Program initiated in the mid-1990s, otherwise known as ubiquitous computing. A few years later, a state-wide oneto-one project initiated in Maine called the Maine Learning Technology Initiative (MLTI) began, with Apple being the winner of the state contract. (Maine Learning Technology Initiative, 2010).In 2006, Apple evaluated the MLTI project and decided to continue it. As of 2010, there were over 4,000 teachers and 53,000 students participating (Fleischer, 2011). Following the success of the MLTI initiative, one-to-one computer projects have appeared all over the globe and the MLTI model became the template for many of these initiatives. Whatever the goal, these one-to-one initiatives all hope to change their school's current system. Weston and Bain (2010) have argued that one-to-one technology initiatives go even farther than other technology-mediated programs have to change schools.

To date, the two most influential research reviews of one-to-one technology use in the classroom were published in 2006 (Penuel, 2006) and in 2011 (Fleischer, 2011). The latter study was a review of peer-reviewed articles concerning one-to-one technology projects published between 2005 and 2010.There have not been any more recent meta-analyses conducted like the scope of Penuel's and Fleischer's, thus the references in this study represent the most recent body of knowledge available to this researcher. 
Penuel (2006) defined one-to-one projects by three criteria or core features,

(1) providing students with use of portable laptop computers loaded with contemporary productivity software (e.g., word processing tools, spreadsheet tools, etc.), (2) enabling students to access the Internet through schools' wireless networks, and (3) a focus on using laptops to help complete academic tasks such as homework assignments, tests, and presentations. (p. 331)

Fleischer (2011) added one additional criterion, "The computer must be used in a personal manner, meaning that one person must have access to the same computer at all times, with the same settings, programs and folder structure" (p. 108).

With the proliferation of one-to-one technology initiatives comes, of course, the desire to justify such projects. Penuel (2006) found four central goals as the impetus for oneto-one computing initiatives: (1) improving academic achievement, (2) increasing equality of access to digital resources and reducing the digital divide, (3) increasing the economic competitiveness of the region, and (4) transforming the quality of instruction. However, Penuel also found in his review of the research that despite huge investments in one-to-one projects, that few high-quality research studies have applied a strict research methodology to the subject. Be that as it may, less empirical reports and project evaluations have been generally positive about the efficacy of one-to-one projects (see e.g., Sauers\& McLeod, 2012). Most results in the studies reviewed by Penuel rely on self-reported data (Penuel, 2006). The survey used in the current study also utilized the self-reported data of the teachers participating in a one-toone technology immersion project in their classrooms.
Numerous improvements have been reported. Clear gains have been observed in writing skills (Silvernail \& Gritter, 2007). Others have reported gains in science education, math, and reading (Sauers \& McLeod, 2012). Besides student achievement, researchers have also found behavioral improvements associated with one-to-one initiatives such as attendance, behavior and motivation (Sauer \& McLeod, 2012).

Despite generally positive reports, oneto-one and other technology initiatives are not without their opponents. Todd Oppenheimer (2003) chronicles decades of failed technology initiatives beginning with Thomas Edison's expansive comments in 1922 that film would replace textbooks, up through the implementation of personal computers. In the early 1980s, Arizona and California offered tax write-offs to entice companies to donate computers to schools. Oppenheimer (1997) also wrote an award-winning piece in The Atlantic Monthly that recounted the beginnings of the digital divide, and failure after failure of school districts, nationwide, to show any positive results from the millions and millions spent on putting computers in the classroom. Haphazard spending, politics, and rash decisions with no factual bases all contributed to the problems. Oppenheimer (2003) quoted Apple founder Steve Jobs, responsible for putting more computers in schools than any other individual, "I used to think technology could help education. But I've come to the inevitable conclusion that what's wrong with education cannot be fixed with technology" (p. 52). What is wrong with education? Oppenheimer says "Education is an institution dominated by the pressures of mediocrity. Schools are places where treating average needs with average amounts of resources has long been the rule - a fact that, unfortunately, has become extremely comfortable and therefore deeply entrenched" (p. 24).Related 
specifically to one-to-one projects, $\mathrm{Hu}$ (2007) found that some schools are ending their oneto-one projects due to costs, or because there was no evidence of the desired educational improvements or outcomes.

Thus, one can find a broad continuum of, as Zucker (2008) calls them "technology utopians" and "technology skeptics," ranging from enthusiastic proponents (Papert, 1993; Sauer \& McLeod, 2012; Seels, 2011) to earnest opponents (Heick, 2012; Oppenheimer, 2003) of technology in the classroom. With this overview, the reader is directed to the current research project, the details of which are delineated next.

\section{Context and Participant}

Of the 1,448 surveys sent out to all teachers in all districts, 307 indicated that they were actually involved in a one-to-one classroom at the time of this study. Thus, the sample population for this study consisted of 307 teachers from five of the 19 southwest Missouri public school districts. Of the valid responses, about $80 \%$ were female and about $20 \%$ were male. The respondents have been teaching in the public schools for a range of 1 to 39 years. Because teachers often teach more than one grade level and were able to indicate this in the survey, the following grade distribution is an approximation: $43 \%$ are pre-K $-6^{\text {th }}$ grade teachers, $14 \%$ teach $7^{\text {th }}$ and $8^{\text {th }}$ grade, and $43 \%$ are $9^{\text {th }}-12^{\text {th }}$ grade teachers. The education level of the participants included Bachelor's, Bachelor's + graduate hours, Masters, Masters plus graduate hours, Ed. Specialist, and Ph.D./Ed.D., although the latter group made up a very small percentage of the population.

Five OERI Districts - Joplin, Monett, Ozark, Reeds Spring, and Willard - had implemented a one-to-one technology initiatives by the start of the 2013-14 academic year. Responses from the teachers in these five districts were analyzed (see Appendix A). The various response categories of the belief statements of the 307 teachers in classrooms that had actually implemented one-to-one technology were analyzed.

\section{Instrumentation}

This research study utilized the Survey design described below. To facilitate data collection, the instrument was an online, interactive questionnaire. A field study was done at the Greenwood Laboratory School at Missouri State University before it was distributed to the general study population. This was to verify the web link to the questionnaire and to check the instrument for readability, typos, ambiguities, and so forth. About seven individuals from Greenwood participated and provided feedback to this researcher, and a few minor revisions has been implemented.

The complete questionnaire (see Appendix B) is divided into three sections. Section 1 requested demographic data, including questions about gender, educational level, years of experience, subject(s) taught, and district/school of employment. Section 2, "Using Technology and Technology Applications" asked the participants to self-report their perceived skill levels with technology and its application in the classroom. Section 3, asked the participants their "Beliefs about Technology Use for Classroom Instruction and Student Learning." The third section was the main focus of this study. In section three, there were a total of 22 items and belief statements that have been mapped to one of the four categories aligned with the Framework for $21^{\text {st }}$ Century Learning: communication, creativity, collaboration and critical thinking, also referred to as the 
"Four Cs," Responses to this section of the questionnaire are reproduced in Appendix A.

\section{Procedures}

Given the number of schools and teachers involved, contacting the teachers directly was logistically unfeasible. Therefore, the link to the questionnaire was distributed to the OERI member superintendents, who approved and then forwarded the link to the building principals in their districts. The principals in turn forwarded the link to the questionnaire via email, to the teachers in their buildings. There was a check box indicating whether or not the teacher was teaching in a one-to-one technology classroom. Only the responses of those teachers who had one-to-one technology in their classrooms were considered in this study. The participating teachers used the link to access the Web-based, interactive questionnaire.

Access to the survey required their consent to participate, which was built into the first page of the questionnaire. The electronic data were stored in a Web form database provided by the researcher's institution and was accessible only to the researcher. The questionnaire was anonymous by which no names had been associated with the responses. The questionnaire asked participants for the name of their school districts and building, but all responses had been examined in aggregate; no individual participant could be identified.

\section{Research Design and Statistical Analysis}

This research study utilized the Survey design. Survey research is a preexperimental, descriptive research method which is useful when researchers wish to collect data on phenomena that cannot be directly observed such as teachers' experiences and beliefs about the use of technology in the classroom (Survey Methods, n.d.). A key characteristic of survey research is that "Researchers gather information with survey questionnaires that ask about individuals' attitudes, opinions, or behaviors. The data is primarily analyzed to describe the average and range of responses" (Clark \& Creswell, 2010, p. 175).

In this survey research, the goal (the research question) was to determine, from the participating teachers' perspective, if the use of one-to-one technology impacted any of the "four Cs" of Framework for $21^{\text {st }}$ Century Learning such as communication, creativity, collaboration, and critical thinking.

The typical method of presenting and analyzing survey data is using frequency distributions and descriptive statistics (Hall, n.d.). The survey results for this descriptive study are presented as frequencies and percentages. These frequency distributions and percentages have been generated in SPSS ${ }^{\text {TM }}$.

\section{Results}

Appendix A contains a summary of the participant responses to those 22 questions from the original questionnaire 
specifically related to the "Four Cs." The responses express the teachers' beliefs about the use of one-to-one technology immersion in their classrooms relative to the Four "Cs," based on their in-class experiences.

Regarding the instrument utilized, the internal consistency reliability (Cronbach's alpha) of the current administration of the instrument is described as follows.

- Teachers'self-evaluation of their technology skills was assessed through responses on a 20 -item scale, with response options defined as: (1) beginner, (2) intermediate, (3) advanced, and (4) advanced high. These items, when combined into a single scale, were found to be reliable $(\alpha=.980)$.

- Teacher's evaluation of students' communication relied on responses to two questions: Technology use for classroom instruction increases my students reading achievement; and Technology use for classroom instruction increases my students writing abilities. Combining the two questions into a scale produced a reliability coefficient of $(\alpha=.783)$.

- The critical evaluation measure was based on teachers' responses to 12 items (e.g., Technology applications help my students interpret and explain concepts and ideas; Technology applications help my students ask and answer questions for clarification.) Response options ranged from (1) strongly disagree to (4) strongly agree. The reliability of the critical evaluation scale was $(\alpha=$.932).

- The creativity measure was based on teachers' responses to 7 items (e.g.,
Technology use in the classroom increases my students' intrinsic motivation; Technology use in the classroom increases my students to generate new and meaningful ideas.) Response options ranged from (1) strongly disagree to (4) strongly agree. The reliability of the critical evaluation scale was $(\alpha=.925)$.

- Collaboration was evaluated on teachers' response to a single question, "Technology use as part of group work encourages students to give and receive help peers." Because this was a single item, reliability analysis was not possible. Response options ranged from (1) strongly disagree to (4) strongly agree. Based on these reliability and validity results, the report of the current study should help generalize the use of the instrument used.

The participants were asked to rate their skill level (beginner, intermediate, advanced, advance high) with technology as part of the survey. Table 1 below delineates the correlation between the teachers' self-reporting of their skill level and their beliefs concerning the Four Cs. Significant correlations are indicated with a double asterisk.

\section{Synopsis of the Findings}

For all questions relating to Critical Thinking, $78.1 \%$ of the participant teachers strongly agreed or agreed that one-to-one technology in the classroom improved student critical thinking skills. For all questions relating to Creativity, $76.5 \%$ of the participant teachers strongly agreed or agreed that one-to-one technology in the classroom improved student creativity. For all questions 
Table 1. The Correlation Between Teacher Skill Self-Report in Application and the Beliefs in 4Cs

\begin{tabular}{|c|c|c|c|c|c|c|}
\hline & & $\begin{array}{l}\text { Teacher } \\
\text { skill } \\
\text { self-report }\end{array}$ & $\begin{array}{l}\text { Critical } \\
\text { thinking }\end{array}$ & Creativity & $\begin{array}{l}\text { Commu- } \\
\text { nication }\end{array}$ & $\begin{array}{l}\text { Colla- } \\
\text { borate }\end{array}$ \\
\hline \multirow{4}{*}{$\begin{array}{l}\text { Teacher skill } \\
\text { self-report }\end{array}$} & Pearson & 1 & .106 & .090 & -.017 & .088 \\
\hline & correlation & & & Male & 26 & 11 \\
\hline & Sig. (2-tailed) & & .064 & .115 & .762 & .123 \\
\hline & $\mathrm{N}$ & 307 & 307 & 307 & 307 & 307 \\
\hline \multirow{4}{*}{$\begin{array}{l}\text { Critical } \\
\text { thinking }\end{array}$} & Pearson & .106 & 1 & $.817^{* *}$ & $.647^{* *}$ & $.701 * *$ \\
\hline & correlation & & & $23-30$ & 72 & 32 \\
\hline & Sig. (2-tailed) & .064 & & .000 & .000 & .000 \\
\hline & $\mathrm{N}$ & 307 & 307 & 307 & 307 & 307 \\
\hline \multirow{4}{*}{ Creativity } & Pearson & .090 & $.817 * *$ & 1 & $.629 * *$ & $.663 * *$ \\
\hline & correlation & & & & & \\
\hline & Sig. (2-tailed) & .115 & .000 & & .000 & .000 \\
\hline & $\mathrm{N}$ & 307 & 307 & 307 & 307 & 307 \\
\hline \multirow{4}{*}{ Communication } & Pearson & -.017 & $.647 * *$ & $.629 * *$ & 1 & $.453 * *$ \\
\hline & correlation & & & 4 & 42 & 19 \\
\hline & Sig. (2-tailed) & .762 & .000 & .000 & & .000 \\
\hline & $\mathrm{N}$ & 307 & 307 & 307 & 307 & 307 \\
\hline \multirow{4}{*}{ Collaborate } & Pearson & .088 & $.701 * *$ & $.663 * *$ & $.453 * *$ & 1 \\
\hline & correlation & & & & & \\
\hline & Sig. (2-tailed) & .123 & .000 & .000 & .000 & \\
\hline & $\mathrm{N}$ & 307 & 307 & 307 & 307 & 307 \\
\hline
\end{tabular}

**. Correlation is significant at the 0.01 level (2-tailed).

relating to Collaboration, $84.8 \%$ of the participant teachers strongly agreed or agreed that one-to-one technology in the classroom improved collaboration among students. For all questions relating to Communication Skills, $70.7 \%$ of the participant teachers strongly agreed or agreed that one-to-one technology in the classroom improved communication skills.
The overall results show that over three-quarters of the teachers $(77.5 \%)$ believe that one-to-one technology in the classroom improves student abilities in one or more of the four areas which the Partnership for $21^{\text {st }}$ Century Learning considers "learning and innovation skills" that "separate students who are prepared for increasingly complex life and work environments in today's world and those 
who are not" (Framework for $21^{\text {st }}$ Century Learning, 2002, 凤4).

\section{Discussion}

As the overall results in this study indicate, the participating teachers believe that one-to-one technology positively impacts students' communication, collaboration, creativity and critical thinking (4Cs) skills. Some districts who were implementing one-to-one technology were doing so to learn more about how to improve the effectiveness of this initiative, while other districts were implementing pilot projects to better understand the issues related to district-wide implementation. Several districts were implementing one-to-one technology only in the high school grades, while others included the middle school grades, and at least one district was planning to extend the initiative into the upper elementary grades.

It has been suggested that the use of technology can be more effective by immersing schools in technology rather than through the typical phased implementations. Shapley, Sheehan, Maloney and Caranik as-Walker (2010) found, after four implementation years, that a technology immersion program can be implemented with reliability. A key factor was the commitment of the stakeholders. Their study was part of the Technology Immersion Pilot created in 2003 by the Texas legislature, "If districts and schools are committed to the model's specifications, especially students' personal access to laptops within and outside of school, the prospects for raising academic achievement are promising" (p. 50).

Teacher professional development has also been found to directly impact the success of one-to-one projects (Drayton, Falk, Stroud, Hobbs, \& Hammerman, 2010; Warschauer 2007). Penuel (2007) found "Formal professional development had been a critical component of many large-scale and smaller one-to-one programs" (p. 338). Penuel's analysis of the research also found that teacher attitudes and beliefs influenced the success of the programs with which they were involved. While there were questions in the original questionnaire addressing these (and other) topics, those questions did not directly relate to the Four "Cs" and were not included in this study.

This research also had some limitations. One could reasonably suggest that the digital divide (the lack of access to technology by all students) is a limitation of any classroom technology initiative. This exploratory study has been designed to 'test the waters' to ascertain the usefulness, if any, of one-toone technology in the local classrooms. Providing all students in all districts with technology would be a huge pedagogical and financial commitment. To even consider doing so, without some positive local feedback from the teachers involved would just be more of what Oppenheimer (1997) called haphazard spending and rash decisions with no factual basis. In the current economic environment, clearly no school system can fully fund every technology project. Also, external 
funding by organizations such as the Ford Foundation and Apple have their limits. The OERI is looking for that 'factual basis' before making a deeper commitment to shrinking the digital divide in their districts via a one-to-one technology initiative.

\section{Implications and Future Research}

The results of this study would suggest several directions for future research. First, additional studies could focus on how grade-level affects this type of technology-mediated learning. For example, would secondary grade levels benefit more from a one-to-one technology immersion than elementary? Researchers might focus on a specific type of one-toone technology such as comparing results from using laptops to using tablets. As mentioned earlier, one-to-one technology immersion has been shown to enhance other learning areas besides the Four C's such as writing skills, science education, academic achievement, and other areas. Florida's Leveraging Laptops Initiative indicated overall positive results in regard to academic achievement (Dawson, Cavanaugh, \& Ritzhaupt, 2006). Thus, directly measuring pre- and postimplementation achievement scores in any number of academic areas within a school district could prove fruitful.

Future research also could investigate whether or not retention is affected by learning achieved in a one-to-one learning environment. Thus, any number of variations on the current study could help teachers and administrators make appropriate, evidence-based decisions about the implementation of technology for their districts.

\section{Conclusion}

In answer to the research question, this study clearly indicated that the OERI teachers observed improved learning in their classrooms, specifically communication, collaboration, creativity, and/or critical thinking, as a result of one-to-one technology immersion. This researcher agrees with Bebelland Kay (2010) who state " study results should not be viewed as a definitive assessment of one-to-one computing and educational technology, but an example of the potential (emphasis added) of one-toone computing" (p. 54).This researcher believes the potential is substantial.

Any technology implementation, including a one-to-one technology immersion, is going to be impacted by the culture of the school or district. Drayton, Falk, Stroud, Hobbs, and Hammerman (2010) state that school culture, and particularly the 'technology culture' of the school, can affect teachers' usage of any new technology tools. These researchers suggest "While individual teachers will use new tools according to their own professional preferences, it is nevertheless the case that school culture can foster collaborative conversations, and the development of innovations - or hinder them" (p. 49).

Districts that plan to implement a oneto-one technology initiative should review the literature, both positive and negative, 
in order to avoid the potential pitfalls. Sauers and McLeod (2012) suggest,

As schools consider moving to one-toone computing, there are many factors to take into consideration. Teachers and administrators should carefully consider the outcomes that they would like to see and then design their implementation, training, and assessment efforts accordingly. (p. 6)

This researcher also believes, as Weston and Bain (2010) suggest, that "...one-to-one initiatives can be fertile ground for the creation of new-paradigm schools, schools that are self-organizing. The widespread availability of laptop computers can be a driver for the more expansive efforts that must happen in order for schools to meet the educational needs of all students" (p. 14). As professional educators, meeting the needs of all students is a primary responsibility, and hopefully a passion as well.

\section{References}

Bebell, D.,\& Kay, R. (2010). One to one computing: A summary of the quantitative results from the Berkshire wireless learning initiative. The Journal of Technology, Learning, and Assessment,9(2). 5-59.

Bebell, D.,\&O’Dwyer, L. M. (2010). Educational outcomes and research from one-to-one computing settings. The Journal of Technology, Learning, and Assessment,9(1), 1-16.

Clark, V., \& Creswell, J. (2010). Understanding research: A consumer's guide. Upper Saddle River, NJ: Merrill (Pearson Education).

Dawson, K., Cavanaugh, C., \&Ritzhaupt, A. (2006). Florida's EETT Leveraging Laptops Initiative and its impact on teaching practices. Journal of Research on Technology in Education, 42(2), 143-159.

Drayton, B., Falk, J. K., Stroud, R., Hobbs, K., \&Hammerman, J. (2010). After installation: Ubiquitous computing and high school science in three experienced, high-technology schools. The Journal of Technology, Learning, and Assessment,9(3), 1-57.

Fleischer, H. (2011). What is our current understanding of one-to-one computer projects: A systematic narrative research review.Educational Research Review, $7(2), 107-122$.

Framework for $21^{\text {st }}$ Century Learning. (2002). Partnership for $21^{\text {st }}$ Century Skills website. Washington, D.C. Retrieved from http:// www.p21.org/storage/documents/1._p21_ framework_2-pager.pdf

Hall, S. (n.d.). What statistical tools of analysis are used in survey research? eHow. Retrievedfrom http://www.ehow.com/ about 5124851 statistical-analysis-usedsurvey-research.h.html 
Heick, T. (2012). 5 problems with technology in classrooms. Teach Thought. Retrievedfrom http://www.teachthought. com/learning/ 5 -problems-withtechnology-in-classrooms/

Hirumi, A. (2011) Does the use of technology improve learning? The answer lies in design. STEM White Paper. Retrieved from https://www.mheonline.com/ glencoemath/pdf/technology.pdf

Hu, W. (2007). Seeing no progress, some schools drop laptops. Retrieved from http://www.nytimes.com/2007/05/04/ education/04laptop.html.

Maine Learning Technology Initiative (2010). About MLTI, 2011. Retrieved fromhttp:// www.maine.gov/mlti/about/index.shtml

Missouri State University. (2013). Ozarks Educational Research Initiative (OERI). Retrieved from http://education. missouristate.edu/isi/91121.htm

Oppenheimer, T. (2003). The flickering mind: The false promise of technology in the classroom and how learning can be saved. New York: Random House.

Oppenheimer, T. (1997, July). The computer delusion. The Atlantic Monthly.Retrieved fromhttp://www.theatlantic.com/ magazine/archive/1997/07/the-computerdelusion/376899/

Papert, S. (1993). The children's machine: Rethinking school in the age of the computer. New York: Basic Books.

Penuel, W. (2006). Implementation and effects of one-to-one computing initiatives: A research synthesis. Journal of Research on Technology in Education, 38(3), 329-348.

Prensky, M. (2001a). Digital natives, digital immigrants. On the Horizon, 9(5), 1-5.

Sauers, N., \& McLeod, S. (2012, May). What does the research say about school oneto-one computing initiatives? (Issue Brief No. 1). Lexington, KY: UCEA Center for the Advanced Study of Technology Leadership in Education.
Retrieved from http://www.natickps.org/ CASTLEBrief01_LaptopPrograms.pdf

Seels, B. (2011). From dale to delivery systems: The problem of media selection theory. In G. Anglin (Ed.). Instructional technology, past, present and future (3rd Ed.) (pp. 55-68). Santa Barbara, CA: Libraries Unlimited.

Shapley, K., Sheehan, D., Maloney, C., \&Caranikas-Walker, F. (2010). Evaluating the implementation fidelity of technology immersion and its relationship with student achievement. The Journal of Technology, Learning, and Assessment,9(4), 1-69.

Survey Methods. (1999). University of Texas Libraries. Retrieved from http://www. ischool.utexas.edu/ palmquis/courses/ survey.html\#TOP

Warschauer, M. (2007). Information literacy in the laptop classroom. Teachers College Record, 109(11), 2511-2540.

Weiser, M. (1991). The computer for the $21^{\text {st }}$ century. Scientific American,265(3), 94101.

Weston, M., \& Bain, A. (2010). The end of techno-critique: The naked truth about one-to-one laptop initiatives and educational change. The Journal of Technology, Learning, and Assessment,9(6), 1-25.

Zucker, A. (2008). Transforming schools with technology. Cambridge, MA: Harvard Education Press.

\section{Contact the Author}

\section{Ching-Wen Chang}

Associate Professor, College of Education, Missouri State University

Email: CChang@missouristate.edu 


\section{Appendix A}

Beliefs about Technology Use for Classroom Instruction and Student Learning

\begin{tabular}{|c|c|c|c|c|c|}
\hline Critical Thinking & SD & D & $\mathbf{A}$ & SA & N/A \\
\hline $\begin{array}{l}\text { 21. Technology applications help my students } \\
\text { ask and answer questions for clarification. }\end{array}$ & 2.48 & 9.50 & 58.68 & 26.03 & 3.31 \\
\hline $\begin{array}{l}\text { 22. Technology applications help my students } \\
\text { define terms. }\end{array}$ & 0.41 & 7.85 & 57.44 & 30.99 & 3.31 \\
\hline $\begin{array}{l}\text { 23. Technology applications help my students } \\
\text { identify assumptions. }\end{array}$ & 2.49 & 15.35 & 61.51 & 12.86 & 7.88 \\
\hline $\begin{array}{l}\text { 24. Technology applications help my students } \\
\text { interpret and explain concepts and ideas. }\end{array}$ & 2.07 & 7.88 & 59.34 & 26.56 & 4.15 \\
\hline $\begin{array}{l}\text { 25. Technology applications help my students } \\
\text { make predictions. }\end{array}$ & 1.66 & 13.28 & 59.34 & 18.67 & 7.05 \\
\hline $\begin{array}{l}\text { 26. Technology applications help my students } \\
\text { see both sides of an issue. }\end{array}$ & 2.07 & 7.47 & 59.26 & 28.22 & 4.98 \\
\hline $\begin{array}{l}\text { 27. Technology use in the classroom increases } \\
\text { my students' flexibility in responding to } \\
\text { others and events. }\end{array}$ & 2.08 & 7.08 & 52.50 & 33.33 & 5.00 \\
\hline $\begin{array}{l}\text { 28. Technology use in the classroom increases } \\
\text { my students' desire to be well-informed. }\end{array}$ & 2.50 & 16.67 & 50.42 & 26.67 & 3.75 \\
\hline $\begin{array}{l}\text { 29. Technology use in the classroom increases } \\
\text { my students' respect for others' viewpoints. }\end{array}$ & 2.90 & 19.92 & 55.60 & 15.77 & 5.81 \\
\hline $\begin{array}{l}\text { 30. Technology use in the classroom increases } \\
\text { my students' inquisitiveness. }\end{array}$ & 2.07 & 13.28 & 53.53 & 29.05 & 2.07 \\
\hline $\begin{array}{l}\text { 31. Technology use in the classroom increases } \\
\text { my students' propensity to seek reason. }\end{array}$ & 2.93 & 19.25 & 56.49 & 15.06 & 6.28 \\
\hline $\begin{array}{l}\text { 32. Technology use in the classroom increases } \\
\text { my students' background knowledge. }\end{array}$ & 0.83 & 7.92 & 56.25 & 32.50 & 2.50 \\
\hline Creativity & SD & D & $\mathbf{A}$ & SA & $\mathbf{N} / \mathbf{A}$ \\
\hline $\begin{array}{l}\text { 33. Technology use in the classroom increases } \\
\text { my students' intrinsic motivation. }\end{array}$ & 7.95 & 19.83 & 49.79 & 20.50 & 2.93 \\
\hline $\begin{array}{l}\text { 34. Technology use in the classroom increases } \\
\text { my students' willingness to take intellectual } \\
\text { risks, such as sharing tentative ideas. }\end{array}$ & 4.15 & 16.60 & 52.28 & 21.16 & 5.81 \\
\hline $\begin{array}{l}\text { 35. Technology use in the classroom increases } \\
\text { my students' willingness to learn new things. }\end{array}$ & 1.67 & 10.46 & 56.90 & 28.87 & 2.09 \\
\hline
\end{tabular}


The Efficacy of a One-to-one Technology Initiative in Improving the Four Cs Journal of Educational Technology Development and Exchange

\section{Appendix A}

Beliefs about Technology Use for Classroom Instruction and Student Learning

\begin{tabular}{|c|c|c|c|c|c|}
\hline Creativity & SD & D & $\mathbf{A}$ & $\mathbf{S A}$ & $\mathbf{N} / \mathbf{A}$ \\
\hline $\begin{array}{l}\text { 36. Technology use in the classroom increases } \\
\text { my students' willingness to take risks and } \\
\text { make mistakes. }\end{array}$ & 3.73 & 19.09 & 51.87 & 19.50 & 5.81 \\
\hline $\begin{array}{l}\text { 37. Technology use in the classroom increases } \\
\text { my students' openness to new ideas. }\end{array}$ & 2.50 & 10.83 & 59.58 & 23.75 & 3.33 \\
\hline $\begin{array}{l}\text { 38. Technology use in the classroom increases } \\
\text { my students' tolerance of ambiguity. }\end{array}$ & 2.93 & 22.18 & 55.65 & 10.46 & 8.79 \\
\hline $\begin{array}{l}\text { 39. Technology use in the classroom increases } \\
\text { my students to generate new and meaningful } \\
\text { ideas. }\end{array}$ & 2.52 & 12.18 & 61.76 & 20.17 & 3.36 \\
\hline Collaboration & SD & D & $\mathbf{A}$ & SA & $\mathbf{N} / \mathbf{A}$ \\
\hline $\begin{array}{l}\text { 40. Technology use as part of group work } \\
\text { encourages students to give and receive help } \\
\text { among peers. }\end{array}$ & 1.25 & 5.83 & 60.42 & 27.92 & 4.58 \\
\hline Communication & SD & D & $\mathbf{A}$ & SA & $\mathbf{N} / \mathbf{A}$ \\
\hline $\begin{array}{l}\text { 41. Technology use for classroom instruction } \\
\text { increases my students reading achievement. }\end{array}$ & 3.73 & 19.50 & 53.53 & 16.18 & 7.05 \\
\hline $\begin{array}{l}\text { 42. Technology use for classroom instruction } \\
\text { increases my students writing abilities. }\end{array}$ & 6.22 & 23.65 & 49.79 & 14.11 & 6.22 \\
\hline
\end{tabular}

Note. Strongly Disagree (SD); Disagree (D); Agree (A); Strongly Agree (SA); Not Applicable $(N A)=$ Statement does not apply in my classroom . 


\section{Appendix B}

Ozarks Educational Research Initiative Teacher Survey for Using Technology in the Classroom

1. In what school district are you employed?

2. In what school building are you employed?

3. Select the grade/s you are currently teaching:

$\begin{array}{llllllllllllll}\mathrm{PK} & \mathrm{K} & 1 & 2 & 3 & 4 & 5 & 6 & 7 & 8 & 9 & 10 & 11 & 12\end{array}$

4. Please indicate the subject/s you teach if you are not responsible for teaching all subjects.

5. What is your gender? Female Male

6. What is the highest level of education you have completed? (Indicate only one choice) Bachelors Bachelors + additional graduate hours

_ Masters Masters + additional graduate hours

Specialist Ph.D. / Ed.D.

7. How many years have you been employed as a professional educator? \# of years

8. How many years have you worked at the school where you are currently employed? \# of years

9. How many years have you been in your current position at this school? \# of years

\section{Using Technology and Technology Applications}

Use the following descriptors to identify your skill level with technology devices and software applications

\begin{tabular}{llllll}
\hline Items & B & I & A & AH \\
\hline
\end{tabular}

1. My current skill level using technology to plan instruction.

2. My current skill level using technology to deliver classroom instruction.

3. My current skill level using technology to enhance student learning.

4. My current skill level using technology to accommodate the different learning styles of my students.

5. My current skill level using technology to provide differentiated instruction for my students. 


\section{Using Technology and Technology Applications}

Use the following descriptors to identify your skill level with technology devices and software applications

\begin{tabular}{llllll}
\hline Items & B & I & A & AH \\
\hline 6.
\end{tabular}

6. My current skill level using technology applications to enhance my students' information literacy and technology skills.

7. My current skill level using technology applications to enhance my students' communication skills.

8. My current skill level using technology applications to improve my students' abilities to collaborate on learning experiences.

9. My current skill level using technology applications to help my students to analyze arguments, claims or evidence.

10. My current skill level using technology applications to help my students make inferences using inductive/deductive reasoning,

11. My current skill level using technology applications to help my students evaluate text.

12. My current skill level using technology applications to help my students make decisions.

13. My current skill level using technology applications to help my students identify problems.

14. My current skill level using technology applications to help my students generate ideas.

15. My current skill level using technology applications to help my students solve problems.

16. My current skill level using technology applications to encourage group work among students.

17. My current skill level using technology to encourage my students to share ideas and to listen to other students' perspectives.

18. My current skill level using technology to encourage my students to seek new ways of clarifying differences and resolving problems in their group.

19. My current skill level using technology to allow my students' to construct new understandings and learning by engaging in group work.

20. My current skill level to experiment with technology to create unique instructional materials. 


\section{Beliefs about Technology Use for Classroom Instruction and Student Learning}

The following statements express beliefs about learning and the benefits of using technology to enhance learning and the development of skills. Please mark each statement with one of the following descriptors, which best matches your belief.

\begin{tabular}{lllll}
\hline Belief Statements & SD & D & A & SA \\
\hline $\begin{array}{l}\text { 21. Technology applications help my students ask and answer } \\
\text { questions for clarification. }\end{array}$ & & & & \\
\hline
\end{tabular}

22. Technology applications help my students define terms.

23. Technology applications help my students identify assumptions.

24. Technology applications help my students interpret and explain concepts and ideas.

25. Technology applications help my students make predictions.

26. Technology applications help my students see both sides of an issue.

27. Technology use in the classroom increases my students' flexibility in responding to others and events.

28. Technology use in the classroom increases my students' desire to be well-informed.

29. Technology use in the classroom increases my students' respect for others' viewpoints.

30. Technology use in the classroom increases my students' inquisitiveness.

31. Technology use in the classroom increases my students' propensity to seek reason.

32. Technology use in the classroom increases my students' background knowledge.

33. Technology use in the classroom increases my students' intrinsic motivation.

34. Technology use in the classroom increases my students' willingness to take intellectual risks, such as sharing tentative ideas.

35. Technology use in the classroom increases my students' willingness to learn new things.

36. Technology use in the classroom increases my students' willingness to take risks and make mistakes. 
The Efficacy of a One-to-one Technology Initiative in Improving the Four Cs Journal of Educational Technology Development and Exchange

\section{Beliefs about Technology Use for Classroom Instruction and Student Learning}

The following statements express beliefs about learning and the benefits of using technology to enhance learning and the development of skills. Please mark each statement with one of the following descriptors, which best matches your belief.

\begin{tabular}{lllll} 
Belief Statements & SD & D & A & SA \\
\hline
\end{tabular}

37. Technology use in the classroom increases my students' openness to new ideas.

38. Technology use in the classroom increases my students' tolerance of ambiguity.

39. Technology use in the classroom increases my students to generate new and meaningful ideas.

40. Technology use as part of group work encourages students to give and receive help among peers.

41. Technology use for classroom instruction increases my students reading achievement.

42. Technology use for classroom instruction increases my students writing abilities.

43. Observation of teachers modeling the use of technology is an effective professional learning tool.

44. Having technology coaching supports my incorporation of technology into my instruction.

45. Having technical support readily available facilitates me incorporating technology into my instruction.

46. Professional learning programs on technology have increased my competence to use technology in my classroom.

47. Professional learning about integrating educational technologies into instruction should have follow-up provisions.

48. Technology has increased my teaching effectiveness.

49. The use of technology applications motivates my students to learn.

50. The use of technology in the classroom increases my students' technology skills.

51. The use of technology in the classroom increases my students' skill to use and evaluate content found on the internet.

Note. Strongly Disagree (SD); Disagree (D); Agree (A); Strongly Agree (SA); Not Applicable (NA) = Statement does not apply in my classroom.

Beginning (B) = Have limited skill with technology devices and software applications in the educational setting Intermediate $(\mathrm{I})=$ Have some skill using technology devices and software applications in the educational setting. Advanced (A) = Have skill using technology devices and software applications in creative ways to enhance learning in the educational setting. Advanced High $(\mathrm{AH})=$ Have advanced skill using technology in educational settings and can demonstrate and assist colleagues in applying these skills. 